\title{
Androgen Mitigates Axotomy-Induced Decreases in Calbindin Expression in Motor Neurons
}

\author{
Julio Pérez and Darcy B. Kelley \\ Department of Biological Sciences, Columbia University, New York, New York 10027
}

\begin{abstract}
Androgens can rescue axotomized motor neurons from cell death. Here we examine a possible mechanism for this trophic action in juvenile Xenopus laevis: regulation of a calciumbinding protein, calbindin, after axotomy. Western analysis revealed that a monoclonal antibody to calbindin $D$ specifically recognizes a single $\sim 28 \mathrm{kDa}$ band in $X$. laevis CNS and rat cerebellum. Retrograde transport of peroxidase combined with immunohistochemistry demonstrated that somata, axons, and synaptic terminals of laryngeal motor neurons in nucleus (N.) $\mathrm{IX}-\mathrm{X}$ of $X$. laevis are calbindin-positive. The number of calbindin-positive cells was compared in the intact and axotomized sides of N.IX-X of gonadectomized males that were either hormonally untreated or DHT-treated for 1 month. Although axotomy decreased the number of calbindin-positive
\end{abstract}

cells by $86 \%$ in hormonally untreated males, the decrease was only $56 \%$ in DHT-treated animals. Compared with hormonally untreated animals, the number of calbindin-labeled cells in N.IX-X of DHT-treated males was increased in both the intact (14\%) and axotomized sides (75\%). We conclude that axotomy decreases and that DHT enhances calbindin immunoreactivity in N.IX-X. Axotomy-induced decrease in calbindin immunoreactivity precedes cell loss in N.IX-X and may impair the capacity of motor neurons to regulate cytoplasmic calcium. Androgen-mediated maintenance of calbindin expression is thus a candidate cellular mechanism for trophic maintenance of hormone target neurons.

Key words: dihydrotestosterone; motor neuron death; immunohistochemistry; calcium buffer; androgens; calbindin
Androgens are trophic hormones that prevent the loss of motor neurons either during normal development or after axotomy (Nordeen et al., 1985; Hauser and Torand-Allerand, 1989; Yu, 1989; Pérez and Kelley, 1996). Androgens activate transduction pathways of gene transcription by binding to the androgen receptor (AR), a transcription factor (Berger and Watson, 1989; Beato et al., 1995). In Xenopus laevis, AR is expressed in motor neurons of the nucleus (N.) IX-X that innervate the larynx (Kelley et al., 1975; Pérez et al., 1996). We previously reported that axotomy enhances transcription of AR mRNA in laryngeal motor neurons 1 month after axotomy and that androgen promotes the subsequent survival of axotomized neurons of N.IX-X (Pérez and Kelley, 1996). In this model, cell loss is delayed until 5 months; this time course permits exploration of mechanisms that lead to cell death and trophic mechanisms of androgens that ameliorate motor neuron loss.

An elevation in cytoplasmic calcium is associated with cell death after lesion, including axotomy-induced motor neuron death (Unemiya et al., 1993; George et al., 1995). Intracellular calcium can be regulated in neurons by the activity of calcium channels, by transport into cellular storage compartments, and by calcium-binding proteins (for review, see Blaustein, 1988). We focus here on one calcium-binding protein, calbindin, which may buffer increased levels of calcium associated with cell death, thus exerting a protective action on injured cells (Mattson et al., 1991; Baimbridge et al., 1992). Some support for a protective role of this protein comes from the observation that calbindin-positive

\footnotetext{
Received May 29, 1997; revised July 2, 1997; accepted July 21, 1997.

This work was supported by National Institutes of Health Grant NS19949 and by Fellowship EX95 50691740 from the Ministry of Education and Science, Spain.

Correspondence should be addressed to Dr. Darcy Kelley, Department of Biological Sciences, Columbia University, 911 Fairchild, New York, NY 10027.

Copyright (C) 1997 Society for Neuroscience $0270-6474 / 97 / 177396-08 \$ 05.00 / 0$
}

cells are selectively spared after lesions of the CNS. For instance, calbindin-immunopositive hippocampal cells are spared after excitotoxic-induced cell death (Sloviter, 1989; Mattson et al., 1991), after section of the perforant pathway (Peterson et al., 1996), and after degeneration induced by Ig-G cytotoxicity (BaoKuan et al., 1996).

Here we explore whether regulation of calbindin expression is a candidate mechanism for the trophic effects of androgen on axotomized motor neurons of N.IX-X. We show that calbindin is localized to the somata and to nerve terminals of motor neurons in N.IX-X, a result that contrasts with the apparent absence of calbindin expression in motor neurons in other animal models (Jande et al., 1981; García-Segura et al., 1984; Séquier et al., 1991). Axotomy decreases and androgen increases calbindin immunoreactivity in N.IX-X; as a result, androgens mitigate axotomy-induced decreases in calbindin expression in motor neurons. The results suggest that one way in which androgens can contribute to motor neuron survival is via control of calcium homeostasis by regulation of calcium-binding proteins.

\section{MATERIALS AND METHODS}

Animals, axotomy, and hormone treatment. Three-month-old postmetamorphic juvenile male frogs (11 animals, 3.0-7.6 gm) obtained from Nasco (Fort Atkinson, WI) were gonadectomized under anesthesia with $0.1 \%$ 3-aminobenzoic acid ethyl ester (MS-222, Sigma, St. Louis, MO). The larynx was accessed through an incision in the body wall; the right IX-X nerve was separated from the laryngeal muscle and severed, and $\sim 1 \mathrm{~cm}$ of the proximal segment was removed. Four males $(n=4)$ were implanted with a SILASTIC tube (VST 030065, Dow Corning, Midland, MI) containing $5 \mathrm{mg}$ of DHT ( $5 \alpha-17 \beta$-ol-3-one androstan; dihydrotestosterone, Sigma) while four males (hormonally untreated) received an empty tube placed into the dorsal lymph sac. One month after gonadectomy, tube implantation and denervation animals were anesthetized deeply and transcardially perfused with $5 \mathrm{ml}$ of $0.6 \% \mathrm{NaCl}$, followed by $10 \mathrm{ml}$ of $4 \%$ paraformaldehyde in $1 \times$ PBS $(2.6 \mathrm{~mm} \mathrm{KCl}, 1.4 \mathrm{~mm}$ $\mathrm{KH}_{2} \mathrm{PO}_{4}, 136 \mathrm{~mm} \mathrm{NaCl}$, and $8 \mathrm{~mm} \mathrm{Na}_{2} \mathrm{HPO}_{4}, \mathrm{pH}$ 7.2). The brain and 
spinal cord (CNS) and the larynx were removed and post-fixed for $2 \mathrm{hr}$ in $4 \%$ paraformaldehyde, followed by immersion in $20 \%$ sucrose in $1 \times$ PBS for 4-12 hr. Sections of the CNS were mounted consecutively onto different slides: the first section was stained with cresyl violet, the second section subjected to immunohistochemistry, the third section was not processed, and so forth. Three additional gonadectomized and DHTtreated males were not axotomized; crystals of horseradish peroxidase (HRP) were inserted into the laryngeal muscle, and the animals were allowed a survival period of $3 \mathrm{~d}$. Animals were perfused, and cryostat sections of the CNS were obtained as described above.

Immunohistochemistry. Cryostat sections of the CNS and larynx were air-dried, immersed in a methanol- $-0.5 \% \mathrm{H}_{2} \mathrm{O}_{2}$ solution for $30 \mathrm{~min}$, and then washed in $0.1 \mathrm{M}$ Tris- $\mathrm{HCl}$. After a $30 \mathrm{~min}$ incubation in a solution containing $2 \%$ BSA and $0.3 \%$ Triton $\mathrm{X}-100$ in $0.1 \mathrm{M}$ Tris- $\mathrm{HCl}$, sections were incubated overnight with mouse monoclonal anti-calbindin $\mathrm{D}$ antibody (clone CL-300, C-8666; Sigma), which has been used previously to demonstrate calbindin immunoreactivity in the dorsal rhombencephalon of $X$. laevis (Muñoz et al., 1995). To determine the optimal antibody concentration, we first incubated sections of the Xenopus CNS with increasing concentrations; a 1:400 concentration of calbindin antibody saturated the immunohistochemical reaction and was used for the comparison of the experimental groups. On the next day, sections were washed and incubated with 1:200 biotinylated horse anti-mouse IgG for $30 \mathrm{~min}$ and then with avidin-biotin-peroxidase complex (ABC) according to the manufacturer's specifications (Vectastain, Vector Laboratories, Burlingame, CA). After washing in Tris buffer, sections were covered with a $0.05 \%$ solution of $3^{\prime}, 3^{\prime}$ diaminobenzidine in $0.05 \mathrm{M}$ Tris- $\mathrm{HCl}$ plus $0.05 \% \mathrm{H}_{2} \mathrm{O}_{2}$ for $\sim 5 \mathrm{~min}$ to give a brown cytoplasmic reaction. Finally, sections were dehydrated and coverslipped. As a control for specificity, sections of the larynx and the CNS were incubated without primary antibody, followed by the $\mathrm{ABC}$ method and diaminobenzidine solution, as described above.

For double labeling of motor neurons, sections were incubated first in a diaminobenzidine solution containing $16 \mathrm{mg} / \mathrm{ml} \mathrm{CoCl}_{2}$ and $0.05 \%$ $\mathrm{H}_{2} \mathrm{O}_{2}$ to develop the HRP. This reaction produced a dark brown granular precipitate in the cytoplasm of motor neurons. After washing, sections were incubated with the calbindin antibody, secondary antibody, and $\mathrm{ABC}$ method, as described above. The $\mathrm{ABC}$ complex was visualized by using a $0.003 \%$ tetramethylbenzidine solution (heated to $60^{\circ} \mathrm{C}$ in $95 \%$ ethanol and dissolved in $10 \mathrm{~mm}$ sodium tungstate and $0.6 \mathrm{~mm}$ ammonium molybdate, $\mathrm{pH}$ 6) plus $0.05 \% \mathrm{H}_{2} \mathrm{O}_{2}$ for $2-3 \mathrm{~min}$. Calbindin immunoreactivity appeared as a green cytoplasmic reaction.

To analyze calbindin immunoreactivity at the neuromuscular junction, we killed two additional males (3 months old and 2 years old), as described previously. The larynx was removed, and sagittal sections (40 $\mu \mathrm{m})$ were prepared with a vibratome (Vibratome, series 1000). Floating sections were processed immunohistochemically, as described above. After dehydration in a graded series of ethanol, sections of the muscle were immersed in xylene and mounted on slides; muscle fibers were dispersed manually with forceps and then coverslipped with Permount.

Western blot. Proteins from Xenopus CNS and rat cerebellum were extracted with a Polytron in a solution of 2 mM EDTA, 1\% SDS, $10 \%$ glycerol, and $62.5 \mathrm{~mm}$ Tris- $\mathrm{HCl}, \mathrm{pH} 7.0$, and stored at $-20^{\circ} \mathrm{C}$. Proteins were separated in $12 \%$ polyacrylamide gels and transferred electrophoretically to nitrocellulose in a buffer containing $193 \mathrm{~mm}$ glycine, 0.025 $\mathrm{M}$ Tris, $0.1 \%$ SDS, and $20 \%$ methanol, $\mathrm{pH}$ 8.3. Transfer of proteins was verified by staining the gel with $0.1 \%$ Coomassie blue. Lanes containing molecular weight standards (Sigma) were cut out, and blots containing protein samples were treated with 5\% Carnation nonfat-dried milk in Tris-HCl, pH 7.4, for $2 \mathrm{hr}$. Membranes containing Xenopus samples were incubated with either anti-calbindin $1: 400$ or without antibody at $-4^{\circ} \mathrm{C}$ overnight. Membranes with rat samples were incubated with either anti-calbindin 1:400 or without antibody for $1 \mathrm{hr}$ at room temperature. After washing, membranes were incubated with biotinylated antibody and $\mathrm{ABC}$ reagents (Vector) at room temperature in $50 \mathrm{~mm}$ Tris- $\mathrm{HCl}$ and $150 \mathrm{~mm} \mathrm{NaCl}, \mathrm{pH} 7.4$, at concentrations used for immunohistochemistry and according to manufacturer's specifications. Immunoreactive bands were visualized by incubation with diaminobenzidine $(5 \mathrm{mg} / 10 \mathrm{ml}$ in 0.01 M Tris) and $0.005 \% \mathrm{H}_{2} \mathrm{O}_{2}$.

Cell quantification and statistical analysis. At perfusion, control and experimental animals were randomly assigned a number from the total corresponding to both groups. On the day of cryostat section, slides were labeled with the number of the animal and numbered sequentially. All reactions were performed on pairs of sections from hormonally untreated and DHT-treated animals. Then sections containing N.IX-X were se- lected for quantification. Calbindin-immunopositive cells were recognized by specific, brown staining of the cytoplasm. For both DHT-treated and untreated juveniles, the effects of axotomy were sufficiently dramatic that a truly "blind" analysis was impossible. Counts of numbers of calbindin-positive cells were obtained by a single observer from coded slides without explicit identification as to treatment group. In material sectioned at $15 \mu \mathrm{m}$, N.IX-X appears on $\sim 20$ sections. For each animal the number of cresyl violet-stained and calbindin-positive cells in the intact and axotomized sides of the entire extent of N.IX-X was determined from tissue sections with a light microscope.

For nuclear and cell diameters (length between the most distant limits of the nuclei or perikarya), three to four nonconsecutive sections containing N.IX-X of all animals were selected at spaced intervals throughout the dorsoventral extent of the nucleus. An average of four cells from each section on each side was chosen randomly and measured with the aid of a calibrated ruler in the microscope ocular. To avoid double counts, we followed two strategies: first, only cells with both cytoplasmic labeling and a visible nucleus were counted. Second, the number of cells was determined from alternating horizontal sections separated by $30 \mu \mathrm{m}$. Because the largest nuclear diameter evaluated in this study was $8.6 \mu \mathrm{m}$, no cell was counted twice. No stereological correction for sampling errors (Abercrombie, 1946) was applied because the diameter of the cell nucleus did not change with DHT treatment, nor did it differ between intact and axotomized sides. All values given are mean \pm SD. Differences in the nuclear and cell diameters, the number of cresyl violetstained cells, and the number of calbindin-positive cells were evaluated by a two-way ANOVA with two between-group factors (treatment, hormonally untreated vs DHT-treated; axotomy, intact vs axotomized sides) followed, when required, by a post hoc Student's two-tailed $t$ test ( $n=4$ per group).

\section{RESULTS}

\section{Calbindin expression in motor neurons of N.IX-X}

N.IX-X is located immediately caudal to the fourth root of cranial nerve IX-X (Fig. 1C). Neurons of N.IX-X are embedded in the white matter of the brainstem lateral to the inferior reticular formation (Simpson et al., 1986). In N.IX-X, cell perikarya and neurites were immunolabeled with the calbindin antibody (Fig. 1A). Calbindin expression elsewhere in the rhombencephalon was limited to the Purkinje cells of the cerebellum, cells of the dorsal tegmental area of the medulla, and sparse cells in the reticular formation and central gray as well as the dorsal rhombencephalic calbindin-expressing nuclei previously described by Muñoz et al. (1995). The dorsal tegmental area of the medulla and the inferior reticular formation are the major sources of afferent input to N.IX-X (Wetzel et al., 1985). In addition to laryngeal motor neurons, cells in the trigeminal and facial nuclei were labeled with the calbindin antibody; no motor neurons in the spinal cord displayed calbindin immunoreactivity (data not shown). Specificity of immunoreactivity was confirmed by the absence of any immunohistochemical reaction in control sections (data not shown).

In DHT-treated animals motor neurons retrogradely labeled with HRP were either calbindin-immunopositive or -negative and were intermingled within N.IX-X, indicating that a subpopulation of motor neurons expresses the protein (Fig. 1A). In the absence of specific markers we cannot determine whether interneurons or glial cells in N.IX-X also express calbindin. Most calbindin-positive cells of N.IX-X that were not labeled with HRP had a motor neuron-like morphology (Fig. 1 $A$ ); because injection of HRP may not have reached all motor neuron terminals, these cells also may have been laryngeal motor neurons. In motor neurons, calbindin immunoreactivity was localized to both the cytoplasm and dendrites (Fig. $1 B$ ). In addition, calbindin was present in axons of the N.IX-X nerve as they left the brainstem (Fig. $1 C$ ). When the nerve was followed to its target laryngeal muscle, calbindin immunoreactivity was seen in unmyelinated 


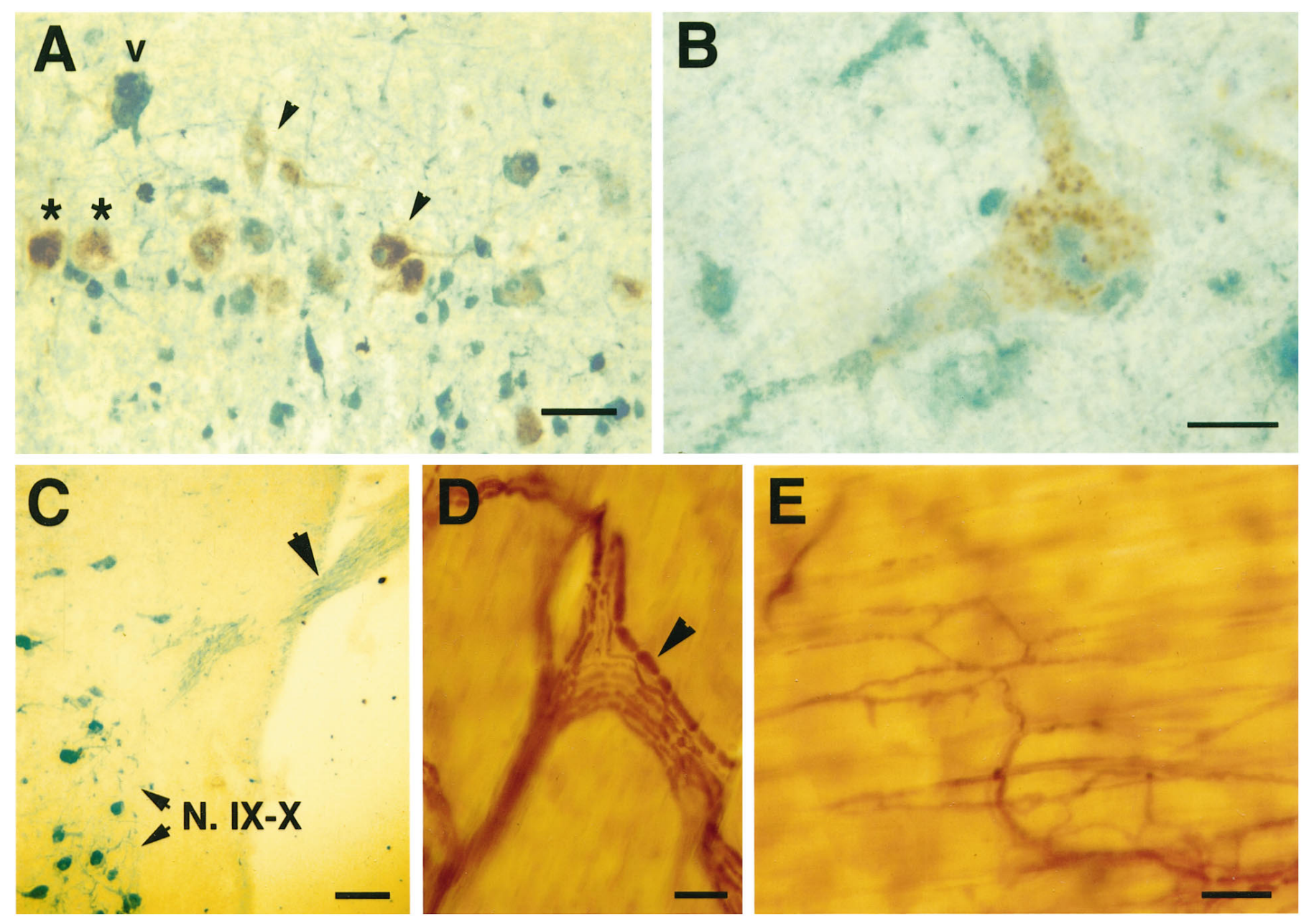

Figure 1. A, Intact motor neurons in N.IX-X of a DHT-treated animal double-labeled with HRP (brown reaction) and calbindin (green reaction). N.IX-X is heterogeneous with respect to calbindin expression: some HRP-labeled motor neurons express calbindin (arrowheads); some motor neurons do not (stars). Some cells with motor neuron-like morphology were not labeled with HRP (v). B, Detail of a motor neuron in N.IX-X; calbindin immunoreactivity is localized to both cytoplasm and dendrites. $C$, Axons from motor neurons of N.IX-X were immunolabeled with calbindin in the laryngeal nerve (arrowhead). D, Within the larynx, unmyelinated axons and Schwann cells associated with myelinated axons (arrowhead) were immunolabeled with calbindin antibody. $E$, Synaptic terminals at the laryngeal neuromuscular junction were immunoreactive for calbindin antibody. Scale bars: $A, 50 \mu \mathrm{m} ; B, 10 \mu \mathrm{m} ; C, 100 \mu \mathrm{m} ; D, E, 25 \mu \mathrm{m}$.

axons, in Schwann cells that form the myelin sheath (Fig. 1D), and in terminals of laryngeal axons at the neuromuscular junction (Fig. 1E). Muscle fibers were not immunoreactive for the calbindin antibody. Calbindin immunoreactivity was found in laryngeal axons in the innervated muscle, whereas no calbindin reaction was found in the denervated side of either hormonally untreated or DHT-treated animals; denervation was confirmed with neurofilament immunolabeling of axons, and denervated muscle was severely atrophied (data not shown). These results indicate that motor neurons do not reinnervate the muscle after 1 month of axotomy, DHT treatment, or both.

The specificity of the calbindin antibody was analyzed by Western blot of proteins from rat cerebellum and Xenopus brain (Fig. 2 ). One band at $\sim 28 \mathrm{kDa}$ was immunolabeled in protein samples from both species. Immunolabeling of this protein was absent in membranes that were not incubated with the calbindin antibody. Because the molecular weight of the labeled protein is that expected for calbindin and because Western analysis revealed a protein of similar size in rat cerebellum (where Purkinje cells express high levels of calbindin; Jande et al., 1981), it is most likely that the immunolabeling reported here represents calbindin-D28k expression in the CNS of $X$. laevis.

\section{Effects of axotomy and DHT treatment on calbindin immunoreactivity of N.IX-X}

Once it was established that motor neurons of N.IX-X contain calbindin, we next analyzed the effect of axotomy and DHT treatment on the expression of this protein.

Axotomy decreases calbindin immunoreactivity in N.IX-X. In hormonally untreated animals a marked decrease in the immunohistochemical signal is noted on the axotomized side, as compared with the intact side (Fig. $3 A$ vs $B$ ). On the axotomized side of N.IX-X, the decrease of immunoreactivity in the neuropil is accompanied by an apparent absence of immunoreactivity in the cytoplasm of cells. An examination of adjacent cresyl violetstained sections reveals that the decrease in calbindin immunoreactivity in the axotomized side of N.IX-X is not attributable to an absence of cells (Fig. $3 A^{\prime}$ ). In hormonally untreated animals, cells of the axotomized side display more intense cresyl violet staining of the cytoplasm than cells of the intact side (Fig. 


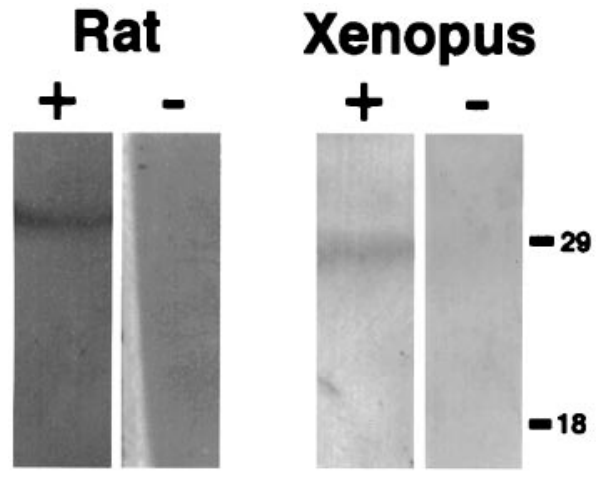

Figure 2. Western blot of total proteins extracted from rat cerebellum or Xenopus brain. Proteins were resolved in $12 \%$ SDS-PAGE and transferred to nitrocellulose. Blots were probed with $(+)$ or without $(-)$ calbindin antibody; one band of $\sim 28 \mathrm{kDa}$, according to molecular weight markers (right), was labeled in both species.

$\left.3 A^{\prime}, B^{\prime}\right)$; cell size also is increased, as compared with the intact N.IX-X (see below). Thus, in hormonally untreated animals, axotomy decreases calbindin immunoreactivity and increases Nissl staining in the cytoplasm of N.IX-X cells.

After DHT treatment, calbindin immunoreactivity was prominent on the intact side of N.IX-X (Fig. 3D). As in hormonally untreated animals, less calbindin immunoreactivity was noted on the axotomized side of N.IX-X (Fig. 3C) than on the intact side (Fig. $3 D$ ). However, DHT treatment appeared to preserve calbindin immunoreactivity in the cytoplasm of axotomized side of N.IX-X, as compared with the axotomized side of hormonally untreated animals (compare Fig. $3 A$ and $C$ ).

In DHT-treated animals, observation of cresyl violet-stained sections, consecutive to those immunolabeled with calbindin antibody, also confirmed that the decreased calbindin immunoreactivity in the axotomized side of N.IX-X was not associated with an apparent loss of cells (Fig. 3C'). In contrast to hormonally untreated animals, Nissl staining in the cytoplasm of cells in N.IX-X of DHT-treated animals did not differ between intact and axotomized sides (Fig. $3 C^{\prime}, D^{\prime}$ ). In DHT-treated animals, cells of the intact side of N.IX-X were more conspicuous and more intensely stained than cells of the intact side of hormonally untreated animals (compare Fig. $3 D^{\prime}$ and $B^{\prime}$ ), whereas cells from the axotomized side of N.IX-X of DHT-treated males did not appear markedly different from untreated males (compare Fig. $3 C^{\prime}$ and $A^{\prime}$ ). Together, these results suggest that both axotomy and DHT treatment affect the cytoplasmic Nissl staining and calbindin immunoreactivity of cells in N.IX-X.

\section{Effects of axotomy and DHT treatment on the number} and size of cresyl violet-stained cells in N.IX-X

The number of cresyl violet-stained cells in N.IX-X was not affected by 1 month of axotomy with or without DHT treatment. The number of cresyl violet-stained cells in N.IX-X of hormonally untreated animals was $233 \pm 113$ and $199 \pm 74$ for the intact and axotomized sides, respectively $(n=4)$. In DHT-treated animals, the number of cells on the intact side was $209 \pm 65$ and on the axotomized side was $201 \pm 75(n=4)$. An ANOVA revealed no significant differences $(p>0.9)$. Thus, axotomy is not accompanied by loss of cells, nor does DHT treatment affect the number of cresyl violet-stained cells in N.IX-X 1 month after treatment.

The size of cells in N.IX-X was affected by treatment (Table
1). There was a significant main effect of both hormone treatment $\left(F_{(1,15)}=8.22 ; p<0.02\right)$ and axotomy $\left(F_{(1,15)}=5.09 ; p<0.05\right)$ on the diameter of perikarya but no significant effect of either treatment on nuclear diameter (for both treatments, $p>0.06$ ). In hormonally untreated animals, cell diameter was increased significantly on the axotomized side $(p<0.03$, Table 1$)$. In contrast, there was no significant difference between sides in nuclear diameter $(p>0.05$, Table 1$)$. We conclude that axotomy increases the size of neurons in hormonally untreated males.

There was a significant two-way interaction between hormone treatment and axotomy on the size of the neuronal perikarya $\left(F_{(1,15)}=7.4 ; p<0.02\right)$ that most likely represents a difference in effects of axotomy on DHT-treated versus untreated animals. In DHT-treated animals no significant differences in either nuclear diameter $(p>0.8)$ or cell diameter $(p>0.7)$ were noted between cells from the intact and from the axotomized sides of N.IX-X (Table 1). Thus, there are no differences in either cell or nuclear diameter of intact and axotomized cells of N.IX-X in animals treated with DHT.

Cell size did differ significantly for the intact sides of N.IX-X of DHT-treated and hormonally untreated animals $(p<0.001$, Table 1); thus DHT increases the size of intact motor neurons. In contrast, no differences were found for the axotomized sides of these groups $(p>0.7)$. Together, the results indicate that both axotomy and DHT treatment increase the size of cell bodies in N.IX-X without significantly affecting nuclear diameter. The effect of axotomy and DHT treatment is neither additive nor synergistic, suggesting a limit to the increase of cell size.

\section{Effects of axotomy and DHT treatment on the number calbindin-immunopositive cells of $\mathbf{N}$.IX-X}

Androgen and axotomy alter calbindin immunoreactivity in N.IX-X. One month after treatment there was a significant main effect of axotomy on the number of calbindin-positive cells in N.IX-X $\left(F_{(1,15)}=27.6, p<0.001\right.$; Figure 4$)$. Axotomy for 1 month was accompanied by a decrease in the number of calbindin-immunoreactive cells in hormonally untreated animals $(86 \%)$ and in DHT-treated animals (56\%). Thus, whether DHTtreated or untreated, axotomy decreased the number of calbindinimmunoreactive cells in N.IX-X.

There was a significant main effect of DHT treatment on the number of calbindin-immunopositive cells in N.IX-X $\left(F_{(1,15)}=\right.$ 5.1, $p<0.05$; Fig. 4) but no significant interaction between hormone treatment and axotomy $\left(F_{(1,15)}=0.35, p>0.5\right)$. For the intact side of N.IX-X, there were $14 \%$ more calbindin-positive cells in DHT-treated animals than in hormonally untreated animals. For the axotomized N.IX-X, there were $75 \%$ more calbindin-immunopositive cells in DHT-treated animals than in hormonally untreated animals (Fig. 4). We conclude that in both the intact and the axotomized N.IX-X, there are more calbindinimmunoreactive cells in DHT-treated than in hormonally untreated animals.

\section{DISCUSSION}

Androgenic steroids have been shown to preserve target motor neurons from cell death both during normal development and in response to axotomy (for review, see Breedlove, 1992; Kujawa and Jones, 1995). We have examined how androgens exert their protective effects in an experimental model system: axotomized laryngeal motor neurons of juvenile Xenopus laevis. Laryngeal motor neurons express high levels of androgen binding and AR mRNA (Kelley, 1981; Pérez et al., 1996) and thus are targets for 


\section{HORMONALLY UNTREATED AXOTOMIZED \\ INTACT}
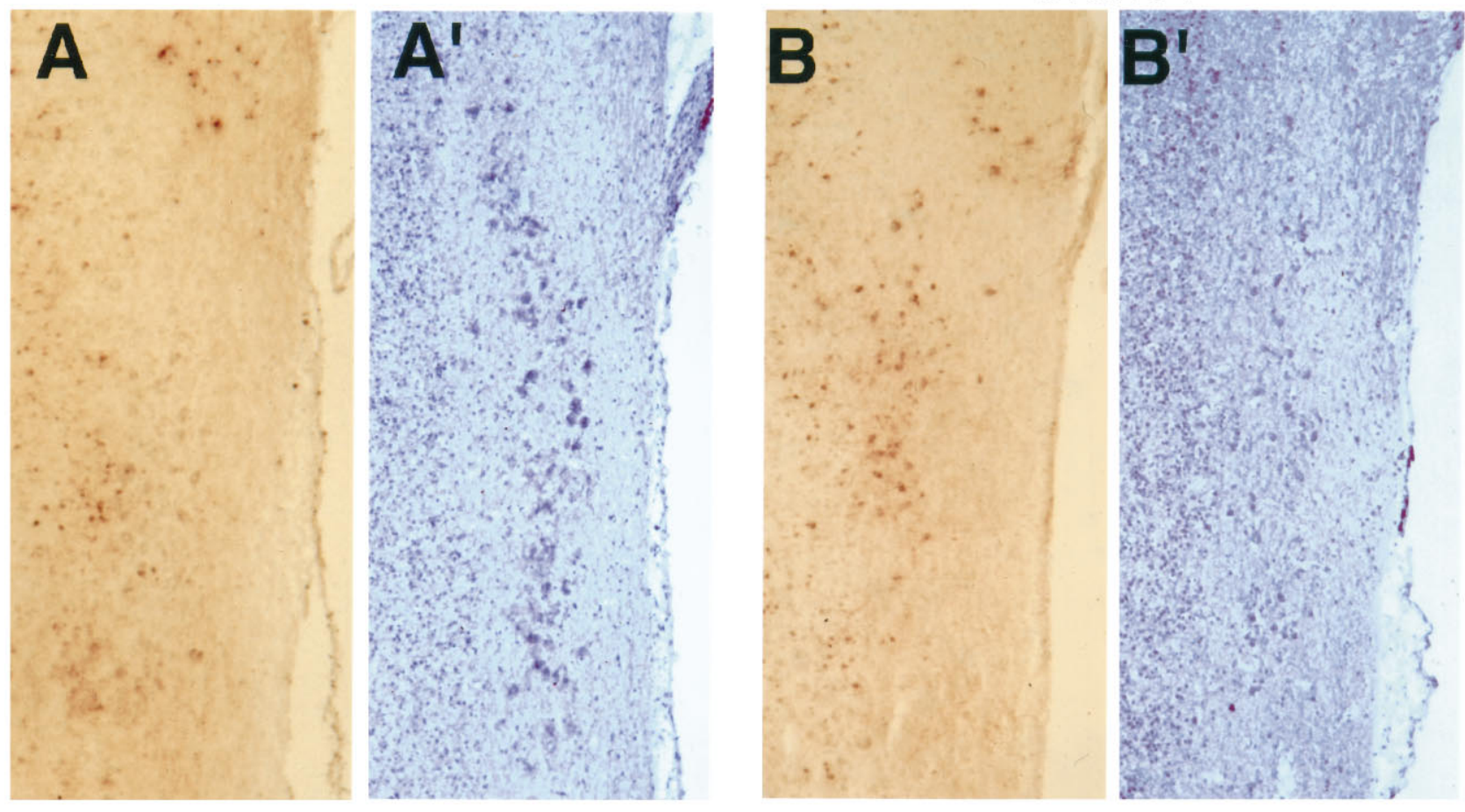

\section{DHT-TREATED}

AXOTOMIZED

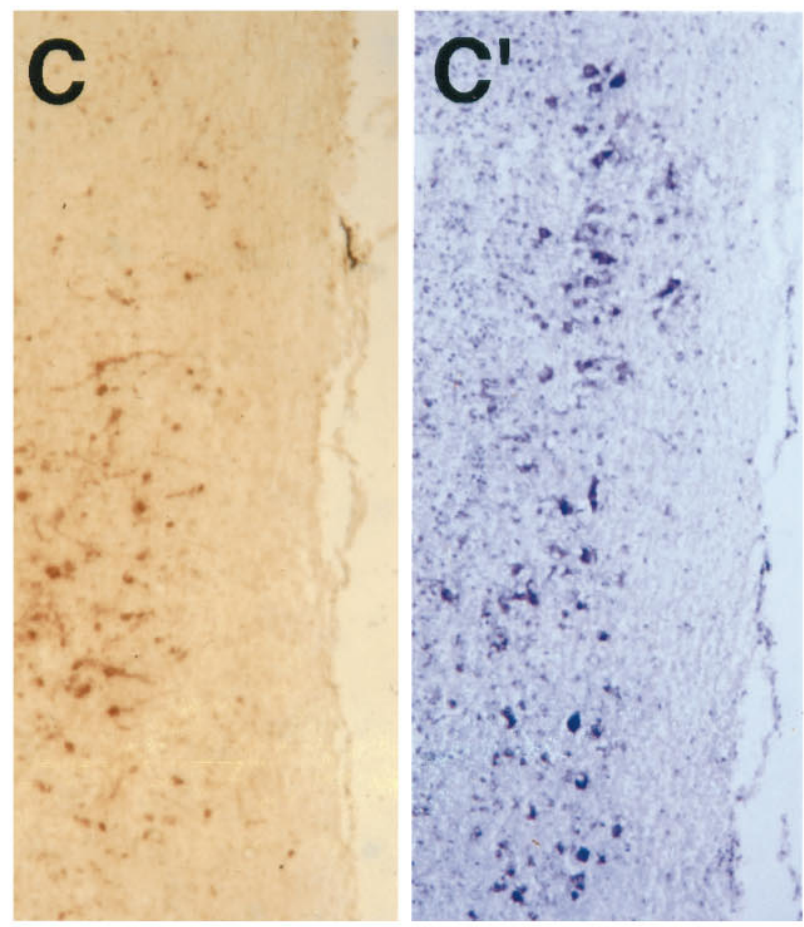

INTACT

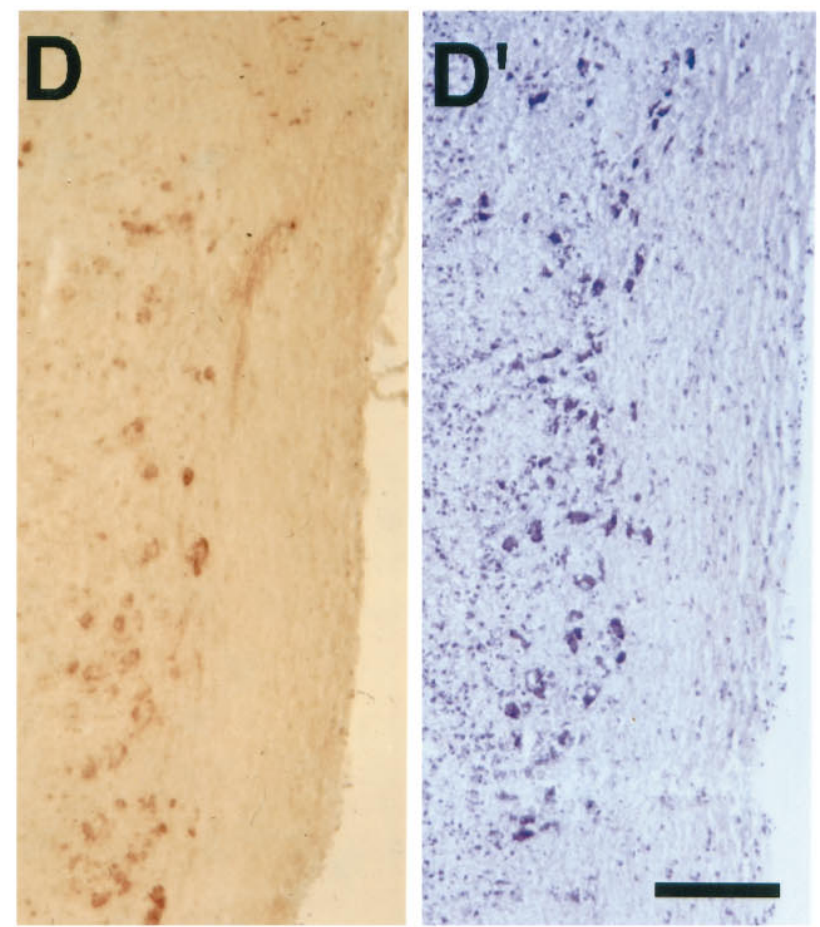

Figure 3. Intact and axotomized sides of N.IX-X in hormonally untreated and DHT-treated animals. Sections were immunolabeled with calbindin antibody, which produced a brown cytoplasmic reaction $(A-D)$, and adjacent sections were stained with cresyl violet $\left(A^{\prime}-D^{\prime}\right)$. In N.IX-X of hormonally untreated animals, axotomy caused a striking decrease in calbindin immunoreactivity (compare $A$ with $B$ ) and an increase in cresyl violet staining of cells (compare $A^{\prime}$ with $B^{\prime}$ ). In DHT-treated animals, axotomy caused a decrease in calbindin immunoreactivity (compare $C$ with $D$ ) in cells of N.IX-X but had no effect on cresyl violet staining (compare $C^{\prime}$ with $D^{\prime}$ ). Scale bar, $200 \mu \mathrm{m}$. 
Table 1. Size of cells in N.IX-X is affected by axotomy and androgen treatment

\begin{tabular}{llllll} 
& \multicolumn{2}{l}{ Hormonally untreated } & & DHT-treated & \\
\cline { 2 - 3 } \cline { 5 - 6 } & Intact & Axotomized & & Intact & Axotomized \\
\hline $\begin{array}{l}\text { Cell diameter } \\
\begin{array}{c}\text { Nuclear } \\
\text { diameter }\end{array}\end{array}$ & $9.5 \pm 1$ & $15.4 \pm 2.6^{*}$ & & $16.2 \pm 1.4^{* *}$ & $15.5 \pm 3.4$ \\
& $3.9 \pm 0.4$ & $6.6 \pm 1.8$ & & $6.1 \pm 1.7$ & $6.3 \pm 1.4$
\end{tabular}

Cell and nuclear diameters $(\mu \mathrm{m})$ in the intact and axotomized sides of N.IX-X of hormonally untreated and DHT-treated animals. Data presented are means \pm SD; $n=4$ animals in all cases. In hormonally untreated animals, axotomy increases the cell diameter in N.IX-X $(* p<0.03)$. In contrast, cell diameters of neurons from the intact and axotomized sides of DHT-treated animals do not differ significantly. On the intact side, DHT treatment increases cell diameter, as compared with untreated animals $\left({ }^{*} p<0.001\right)$. Neither axotomy nor hormonal treatment significantly affected diameters of cell nuclei in N.IX-X (ANOVA, $p>0.5$ ).

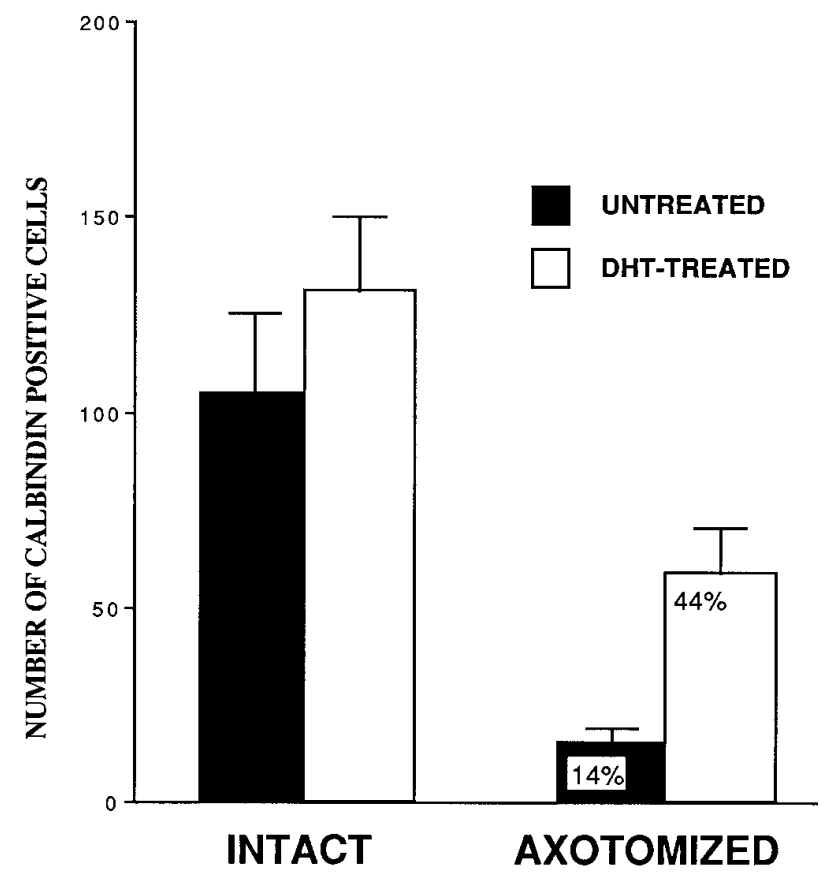

NUMBER OF

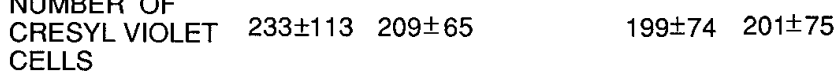

Figure 4. Number of calbindin-immunopositive cells and number of cresyl violet-stained cells (mean $\pm \mathrm{SD} ; n=4$ animals per group) counted in the intact and axotomized N.IX-X of hormonally untreated (black bars) and DHT-treated (white bars) animals 1 month after axotomy. There were no significant differences in the number of cresyl violet-stained cells. There was a significant main effect of hormone treatment $(p<0.05)$ and axotomy $(p<0.01)$ on the number of calbindin-positive cells, but there was no significant interaction between treatments. For the axotomized side, the number of calbindin-immunoreactive cells in the intact sides/ number in the axotomized sides $\times 100$ is displayed within the bars.

this class of hormones. In this system axotomy leads to substantial cell death 5 months later; endogenous or exogenous androgen mitigates axotomy-induced cell loss (Pérez and Kelley, 1996).

What downstream targets of AR activation are involved in the protective effects of androgen? Because elevations in intracellular calcium accompany injury-induced cell death in many neuronal systems, regulation of calcium homeostasis could contribute to cell preservation. We show here that laryngeal motor neurons express calbindin-D28k, a calcium-buffering protein, that axotomy decreases calbindin immunoreactivity, and that androgen treatment preserves immunoreactivity. These findings support the hypothesis that androgen regulation of calbindin expression contributes to its trophic actions on axotomized motor neurons.

\section{Calbindin expression in motor neurons}

Motor neurons of N.IX-X retrogradely labeled with HRP were immunolabeled with calbindin antibody. Does this antibody recognize an authentic calbindin protein in the $X$. laevis CNS? We examined protein blots of $X$. laevis CNS, using a mouse monoclonal antibody with wide cross-species activity. A single band of the appropriate molecular weight $(28 \mathrm{kDa})$ was recognized specifically; a band of the same size also was recognized in rat cerebellum. Although each species has a somewhat idiosyncratic pattern of expression (Baimbridge et al., 1992), in all species examined to date calbindin is expressed in cerebellar Purkinje cells; we also saw expression in this cell type in $X$. laevis. Taken together, the size of the antigen and its characteristic pattern of expression suggest that a calbindin-D28 $\mathrm{kDa}$ is expressed in the CNS of $X$. laevis.

Expression in motor neurons is unusual for calbindin, so much so that modified motor neurons have been used to study the protective effects of transfected calbindin (Ho et al., 1996). Calbindin expression in $X$. laevis is not confined to N.IX-X. Immunopositive cells also were found in the trigeminal and facial nuclei, whereas no label was present in ventral horn of the spinal cord, suggesting that motor neuron expression may be limited to cranial nerve motor nuclei.

Laryngeal motor neuron cell bodies, dendrites, axons, and neuromuscular terminals are all immunopositive for calbindin. In addition, calbindin also is expressed in Schwann cells wrapping the laryngeal axons. The widespread distribution of calbindin in different compartments of the cell suggests participation in a variety of functions requiring regulation of free calcium. The major proposed role for calbindin is regulating intracellular calcium availability (Blaustein, 1988; Baimbridge et al., 1992). In hippocampal neurons, reductions in calbindin lead to increased activation and inactivation of voltage-gated calcium channels (Kohr and Mody, 1991). Calbindin expression in some systems is associated with high rates of spontaneous activity and may play a role in sequestering associated calcium elevations (Blaustein, 1988). In addition, other calcium-binding proteins (e.g., calmodulin) have been shown to inactivate receptors mediating calcium influx, such as the NMDA receptor (Ehlers et al., 1996). At the presynaptic terminal, calbindin does not influence evoked neurotransmitter release but does suppress post-tetanic potentiation (Chard et al., 1995). Having established that calbindin is expressed in laryngeal motor neurons, we explored whether changes in calbindin expression are associated with motor neuron death or survival.

\section{Calbindin, axotomy, and cell death}

We show here that axotomy decreases the number of calbindinimmunoreactive cells in N.IX-X, suggesting that motor neurons deprived of access to target muscles downregulate this protein. Not all proteins, however, are decreased in expression by axotomy. In this study, axotomy increased Nissl staining, a change believed to reflect a general increase in protein synthesis in neurons (Barr and Hamilton, 1948; Lieberman, 1971). Axotomy also increased AR mRNA expression (Pérez and Kelley, 1996). We suggest that downregulation of calbindin expression is a specific response to axotomy that may contribute to the subsequent death of laryngeal motor neurons. 
Increased levels of cytoplasmic calcium are associated with cell death in many systems. Changes in calbindin expression have been observed in the CNS after injury. For instance, kindling reduces calbindin content in granule cells of the dentate gyrus (Köhr and Mody, 1991); Renshaw interneurons decrease calbindin immunoreactivity after axotomy of the presynaptic motor neurons (Sanna et al., 1993), and the number of calbindinimmunopositive cells increases after axotomy of sympathetic ganglion cells (Sánchez-Vives et al., 1994). In patients with Huntington's and Alzheimer's diseases, calbindin expression is downregulated in the forebrain and striatum (Iacopino and Christakos, 1990a).

In motor neurons, analysis of electrophysiological properties after axotomy suggests that these cells experience elevated intracellular calcium; axotomized motor neurons have a larger afterhyperpolarization potential and faster inactivation of calcium currents than intact neurons (Unemiya et al., 1993). Interestingly, these characteristics are reminiscent of the physiology of injured granule cells of the hippocampus that lose calbindin expression (Köhr and Mody, 1991). In addition, axonal degeneration in axotomized motor neurons is mediated via calcium influx (George et al., 1995). In Xenopus laryngeal motor neurons, a decrease in calbindin immunoreactivity is an early response of motor neurons to axotomy that anticipates cell loss. After axotomy, an impaired buffering capacity resulting from decreased calbindin expression may contribute to the elevation of free calcium leading to cell death.

Does the axotomy-induced decrease in calbindin immunoreactivity reflect a decrease in calbindin expression? Calbindin immunoreactivity can be influenced by calcium levels. In biochemical experiments the immunoreactive signals for calbindin in blots from cytosolic extracts of rat cerebellum were directly proportional to calcium concentration in the incubation buffer; formalin fixation reduced, but did not eliminate, calcium effects (Winsky and Kuznicki, 1996). In hippocampal slices opposite results have been obtained: slices preincubated in low calcium showed enhanced immunoreactivity, whereas those in high calcium showed decreased immunoreactivity (Dutar et al., 1991). Both of these studies used the same mouse monoclonal anti-calbindin D antibody used here. Changes in calbindin immunoreactivity induced by axotomy thus may reflect changes in the state of the protein because of altered intracellular calcium levels rather than an actual decrease in protein synthesis or stability. The resolution of these issues awaits the cloning of Xenopus calbindin so that regulation of its mRNA can be studied.

\section{Androgens, calbindin, and cell survival}

In N.IX-X androgen treatment increases cell survival after axotomy (Pérez and Kelley, 1996) and maintains calbindin immunoreactivity (this study). Expression of calbindin also can be regulated by other steroid hormones. For instance, corticosterone induces calbindin expression in the hippocampus (Iacopino and Christakos, 1990b), and calbindin mRNA expression is under the control of estrogen in uterine myometrium (Romagnolo et al., 1996).

In both the intact and axotomized sides of N.IX-X, more calbindin-immunoreactive cells were found in DHT-treated animals than in hormonally untreated animals. Although protective effects of calbindin are controversial (Baimbridge et al., 1992), calbindin is thought to protect injured neurons and glial cells from excitotoxicity via reduction in intracellular calcium levels (Sloviter, 1989; Mattson et al., 1991; Bao-Kuan et al., 1996;
Peterson et al., 1996). Calbindin-immunoreactive cells are spared in in vitro assays of neuronal survival, and calbindin expression is induced by brain-derived neurotrophic factor, tumor necrosis factor, and neurotrophin-3 (NT-3), all of which exert trophic effects on target neurons (Collazo et al., 1992; Mattson et al., 1995; Ventimiglia et al., 1995; Marty et al., 1996). In a model system for amyotrophic lateral sclerosis (IgG-mediated toxicity of hybrid motor neurons), calbindin transfection protects cells from death (Ho et al., 1996). Although the increased expression of calbindin evoked by androgens is not specific to axotomized cells, it might contribute specifically to survival by sustaining cell physiology in a state closer to that of intact motor neurons.

Axotomy induces changes in gene expression: some changes are associated with cell survival and others with neurodegeneration. In laryngeal motor neurons of N.IX-X, axotomy for 1 month induces upregulation of AR mRNA expression. By facilitating androgen binding and thus enhancing the expression of androgen target genes, increased receptor expression may represent the first step in androgen rescue of motor neurons (Pérez and Kelley, 1996). Another such example is the induction of tubulin expression by testosterone in axotomized facial motor neurons of hamsters (Jones and Oblinger, 1994), which may facilitate axonal regeneration (Yu, 1982; Kujawa et al., 1991). In contrast, axotomy decreases calbindin expression, a change that may favor calciummediated cell death. We conclude that one explanation for androgen-mediated cell rescue is increased transcription of "survival" genes and that calbindin may be such a gene.

\section{REFERENCES}

Abercrombie M (1946) Estimation of nuclear population from microtome sections. Anat Rec 94:239-247.

Baimbridge KG, Celio MR, Rogers JH (1992) Calcium-binding proteins in the nervous system. Trends Neurosci 15:303-308.

Bao-Kuan H, Alexianu ME, Colom LV, Mohamed AH, Serrano F, Appel SH (1996) Expression of calbindin-D28k in motoneuron hybrid cells after retroviral infection with calbindin-D28k cDNA prevents amyotrophic lateral sclerosis Ig-G-mediated cytotoxicity. Proc Natl Acad Sci USA 93:6796-6801.

Barr ML, Hamilton JD (1948) A quantitative study of certain morphological changes in spinal motoneurons during axon reaction. J Comp Neurol 89:93-121.

Beato M, Herrlich P, Schütz G (1995) Steroid hormone receptors: many actors in search of a plot. Cell 83:851-857.

Berger FG, Watson G (1989) Androgen-regulated gene expression. Annu Rev Physiol 51:51-65.

Blaustein MP (1988) Calcium transport and buffering in neurons. Trends Neurosci 11:438-443.

Breedlove SM (1992) Sexual dimorphism in the vertebrate nervous system. J Neurosci 12:4133-4142.

Chard PS, Jordán J, Marcuccilli CJ, Miller RJ, Leiden JM, Ross RP, Ghadge GD (1995) Regulation of excitatory transmission at hippocampal synapse by calbindin-D28k. Proc Natl Acad Sci USA 92:5144-5148.

Collazo D, Takahashi H, McKay RDG (1992) Cellular targets and trophic functions of neurotrophin-3 in the developing rat hippocampus. Neuron 9:643-656.

Dutar P, Potier B, Lamour Y, Emson P, Senut M (1991) Loss of calbindin-28k immunoreactivity in hippocampal slices from aged rats; a role for calcium? Eur J Neurosci 3:839-849.

Ehlers MD, Zhang S, Bernhadt JP, Huganir RL (1996) Inactivation of NMDA receptors by direct interaction of calmodulin with the NR1 subunit. Cell 84:745-755.

García-Segura LM, Baetens D, Roth J, Norman AW, Orci L (1984) Immunohistochemical mapping of calcium-binding protein immunoreactivity in the rat central nervous system. Brain Res 296:75-86.

George EB, Glass JD, Griffin JW (1995) Axotomy-induced axonal degeneration is mediated by calcium influx through ion-specific channels. J Neurosci 15:6445-6452.

Hauser KF, Torand-Allerand CD (1989) Androgen increases the num- 
ber of cells in fetal mouse spinal cord cultures: implications for motoneuron survival. Brain Res 485:157-164.

Ho BK, Alexianu ME, Colom LV, Mohamed AH, Serrano F, Appel SH (1996) Expression of calbindin-D28K in motoneuron hybrid cells after retroviral infection with calbindin-D28K cDNA prevents amyotrophic lateral sclerosis IgG-mediated cytotoxicity. Proc Natl Acad Sci USA 93:6796-6801.

Iacopino AM, Christakos S (1990a) Corticosterone regulates calbindinD28k mRNA and protein levels in rat hippocampus. J Biol Chem 265:10177-10180.

Iacopino AM, Christakos S (1990b) Specific reduction of calciumbinding protein (28-kilodalton calbindin-D) gene expression in aging and neurodegenerative diseases. Proc Natl Acad Sci USA 87:4078-4082.

Jande SS, Maler L, Lawson DEM (1981) Immunohistochemical mapping of vitamin D-dependent calcium-binding protein in brain. Nature 294:765-767.

Jones KJ, Oblinger MM (1994) Androgenic regulation of tubulin gene expression in axotomized hamster facial motoneurons. J Neurosci 14:3620-3627.

Kelley DB (1981) Locations of androgen-concentrating cells in the brain of Xenopus laevis: autoradiography with ${ }^{3} \mathrm{H}$-dihydrotestosterone. J Comp Neurol 199:221-231.

Kelley DB, Morrell JI, Pfaff DW (1975) Autoradiographic localization of hormone-concentrating cells in the brain of an amphibian, Xenopus laevis. I. Testosterone. J Comp Neurol 164:47-61.

Köhr G, Mody I (1991) Endogenous intracellular calcium buffering and the activation/inactivation of HVA calcium currents in rat dentate gyrus granule cells. J Gen Physiol 98:941-967.

Kujawa KA, Jones KJ (1995) Trophic actions of gonadal steroids on neuronal functioning normally and following injury. In: Advances in neuronal science, Vol 2, pp 131-152. JAI Press.

Kujawa KA, Emeric E, Jones KJ (1991) Testosterone differentially regulates the regenerative properties of injured hamster facial motoneurons. J Neurosci 11:3898-3906.

Lieberman AR (1971) The axon reaction: a review of the principal features of perikaryal responses to injury. Int Rev Neurobiol 14:49-124.

Marty S, Carroll P, Cellerino A, Castrén E, Staiger V, Thoenen H, Lindholm D (1996) Brain-derived neurotrophic factor promotes the differentiation of various hippocampal nonpyramidal neurons, including Cajal-Retzius cells, in organotypic slice cultures. J Neurosci 16:675-687.

Mattson MP, Rychlik B, Chu C, Christakos S (1991) Evidence for calcium-reducing and excito-protective roles for the calcium-binding protein calbindin-D28k in cultured hippocampal neurons. Neuron 6:41-51.

Mattson MP, Cheng B, Baldwin SA, Smith-Swintosky VL, Keller J, Geddes JW, Scheff KW, Christakos S (1995) Brain injury and tumor necrosis factors induce calbindin D-28k in astrocytes: evidence for cytoprotective response. J Neurosci Res 42:357-370.

Muñoz A, Muñoz M, González A, Donkelaar HJT (1995) Anuran dorsal column nucleus: organization, immunohistochemical characteriza- tion, and fiber connections in Rana perezi and Xenopus laevis. J Comp Neurol 363:197-220.

Nordeen E, Nordeen K, Sengelaub D, Arnold A (1985) Androgens prevent normally occurring cell death in a sexually dimorphic spinal nucleus. Science 229:671-673.

Pérez J, Kelley DB (1996) Trophic effects of androgens: receptor expression and the survival of laryngeal motoneurons after axotomy. J Neurosci 16:6625-6633.

Pérez J, Cohen M, Kelley DB (1996) Androgen receptor mRNA expression in Xenopus laevis CNS; sexual dimorphism and regulation in the laryngeal motor nucleus. J Neurobiol 30:556-568.

Peterson DA, Lucidi-Phillipi CA, Murphy DP, Ray J, Gage FH (1996) Fibroblast growth factor-2 protects entorhinal layer II glutamatergic neurons from axotomy-induced death. J Neurosci 16:886-898.

Romagnolo B, Cluzeaud F, Lambert M, Colnot S, Porteau A, Molina T, Tomasset M, Vandewalle A, Kahn A, Perret C (1996) Tissue-specific and hormonal regulation of calbindin-D9k fusion genes in transgenic mice. J Biol Chem 271:16820-16826.

Sánchez-Vives MV, Valdeolmillos M, Martinez S, Gallego R (1994) Axotomy-induced changes in $\mathrm{Ca}^{2+}$ homeostasis in rat sympathetic ganglion cells. Eur J Neurosci 6:9-17.

Sanna PP, Celio MR, Bloom FE, Rende M (1993) Presumptive Renshaw cells contain decreased calbindin during recovery from sciatic nerve lesions. Proc Natl Acad Sci USA 90:3048-3052.

Séquier JM, Hunziker W, Andressen C, Celio MR (1991) Calbindin D-28k protein and mRNA localization in the rat brain. Eur J Neurosci 2:1118-1126.

Simpson HB, Tobias ML, Kelley DB (1986) Origin and identification of fibers in the cranial nerve IX-X complex of Xenopus laevis: Lucifer yellow backfills in vitro. J Comp Neurol 244:430-444.

Sloviter RS (1989) Calcium-binding protein (Calbindin-D28k) and parvalbumin immunocytochemistry: localization in the rat hippocampus with specific reference to the selective vulnerability of hippocampal neurons to seizure activity. J Comp Neurol 280:183-196.

Unemiya M, Araki I, Kuno M (1993) Electrophysiological properties of axotomized facial motoneurones that are destined to die in neonatal rats. J Physiol (Lond) 462:661-678.

Ventimiglia R, Mather PE, Jones BE, Lindsay RM (1995) The neurotrophins BDNF, NT3, and NT-4/5 promote survival and morphological and biochemical differentiation of striatal neurons in vitro. Eur J Neurosci 7:213-222.

Wetzel D, Haerter U, Kelley D (1985) A proposed neural pathway for vocalization in South African clawed frogs, Xenopus laevis. J Comp Physiol 157:749-761.

Winsky L, Kuznicki J (1996) Antibody recognition of calcium-binding proteins depends on their calcium-binding status. J Neurochem 66:764-771.

Yu W-HA (1982) Effect of testosterone on the regeneration of hypoglossal nerve in rats. Exp Neurol 77:129-141.

Yu W-HA (1989) Administration of testosterone attenuates neuronal loss following axotomy in the brainstem motor nuclei of female rats. J Neurosci 9:3908-3914. 